\title{
ТЕРМІН «ФРАЗЕМА» В ЕТНОЛІНГВІСТИЦІ ТА ЛІНГВОКУЛЬТУРОЛОГІї
}

Кевлюк І. В. Термін «фразема» в етнолінгвістиці та лінгвокультурології.

У статті з'ясовано історико-етимологічну основу терміна «фразема» та проаналізовано їх із позиції внутрішніх форм; досліджено особливості структури фразеологічних одиниць; розглянуто методологічні та теоретичні засади фразеологічного складу мови; простежено взаємозв'язок фразем і культурно-етнографічних факторів.

Ключові слова: фразема, ідіома, фразеологія, фразеологічні одиниці, лексема, лінгвістика, етнолінгвістика, лінгвокультурологія, мовна картина світу.

Кевлюк И. В. Термин «фразема» в этнолингвистике и лингвокультурологии.

В статье исследовано историко-этимологическую основу термина «фразема» и проанализировано еe с точки зрения внутренних форм; исследовано особенности структуры фразеологических единиц; рассмотрено методологические и теоретические основы фразеологического состава языка; прослежена взаимосвязь фразем і культурно-этнографических факторов.

Ключевые слова: фразема, идиома, фразеология, фразеологические единицы, лексема, лингвистика, этнолингвистика, лингвокультурология, языковая картина мира.

Kevlyuk I. V. The term «phraseme» in etnolinguistics and linguistic culture.

In the article historical-etymology base of the term «phraseme» and its internal structure are analyzed. The structural features of phraseological units are researched. The methodological and theoretical principles of phraseological composition of the language are considered. The relationship of cultural and ethnographic factors are trased.

Key words: phraseme, idiom, phraseology, phraseological units, lexeme, linguistics, ethnolinguistics, linguistic culture, linguistic picture of the world.

Останнім часом опубліковано багато наукових праць із проблем фразеології, етнолінгвістики та лінгвокультурології (В. Ужченко, В. Жайворонок, О. Масло, О. Селіванова, В. Яковлєва, М. Скаб, I. Мілєва, I. Сніцар, М. Літвінова, В. Васильченко, Т. Д'якової, Т. Григоренко, О. Плетньова), фігурує значна кількість точок зору щодо поняттєвих та термінологічних розбіжностей, а деякі науковці по-різному підходять до явищ фразеології. Питанням фразеотворення (у науковий обіг термін увів В. Виноградов) присвятили свої праці М. Алефіренко, М. Демський, В. Коваль, В. Білоноженко, І. Гнатюк, Л. Скрипник, Г. Волкотруб, В. Телія, А. Смерчко та інші етимологічні дослідження сприяли закріпленню в українському мовознавстві низки нових термінів на позначення процесу появи нових фразем: фразеологізація (С. Гаврин, В. Ващенко, Г. Удовиченко, В. Кодухов), ідіоматизачія (Б. Ларін), фразеологічні неології (В. Мокієнко), фразеологічні інновачії (В. Русанівський, Н. Кошелова, О. Сербенська, А. Смерчко), неофразеологізація (Н. Скиба). Фразеологія ставить перед перед собою ряд специфічних завдань: проаналізувати взаємозв'язок фразеологічних зворотів з іншими мовознавчими одиницями - словом, словосполученням, реченням; дослідити особливості структури фразеологічних одиниць; з'ясувати історико-етимологічні основи фразем. Детальне вивчення вищезазначених завдань має велике практичне й теоретичне значення. 
Питання фразеологізації як мовно-історичного явища, джерельної та дериваційної бази українських фразем також набувають у сучасному мовознавстві особливої актуальності в аспекті вивчення семантики фразеологічних одиниць унаслідок тривалого розвитку, стабілізації й закріплення у мовленнєвій практиці народу. Його динаміка полягає в лексико-граматичних перетвореннях у напрямі від синтаксично вільних словосполучень до семантично нерозкладних фразеологічних зрощень.

Меншою мірою представлені дослідження фразеологізмів в їх історичному й етимологічному аспектах, спрямовані на вивчення первинних форм і значень, джерел походження фразеологізмів, виявлення сфер їхнього функціонування.

Упорядкування лінтвістичної термінології теж залишається актуальним. Так, немає чіткості у позначенні фразеологічних одиниць різних типів - «усталених зворотів, стійких поєднань слів, що виступають у мові як єдиний неподільний і цілісний вислів» [8, с. 878]. У кожного автора, залежно від його наукових орієнтирів, має місце довільне використання термінів зазначеної сфери номенів: фразеологічний зворот мови, лексикалізована фраза, фразеологізм, фразеологічна одиниця, фразема, сполучення слів 3 переносним значенням, неподільне словосполучення, стійке словосполучення, стійка сполука слів, стійка фраза, ідіоматичне словосполучення, ідіоматизм, ідіома, ідіоматичний вислів. Так само й розділ, що охоплює сукупність цих одиниць, номінують як фразеологія, ідіоматика, фраземіка тощо.

$\mathrm{y}$ наш час лінгвістика вивчає мовні явища у їх взаємозалежності 3 людським фактором і вважає це актуальною тенденцією сьогодення. Цей факт сприяє інтенсивному розвитку етнолінгвістики й лінгвокультурології в рамках фразеології. Ці галузеві напрямки прагнуть простежити спільні ознаки й відмінності проникнення «мови» культури у форми презентації фраземами культурно значимої інформації.

Щодо лінгвокультурології, то ця галузь науки дезінтегрує фразеологічну картину світу на окремі іï складові - фраземи, вивчає їх спроможність віддзеркалювати культурну сучасну самосвідомість етносу. Саме фраземи виражають основні переконання та вірування носіїв мови. В. Телія вважає, що «система образів, закріплених у фразеологічному складі мови, виступає своєрідною «нішею» для комуляції світобачення $\mathrm{i}$, так чи інакше, зв'язана 3 матеріальною, соціальною чи духовною культурою даної мовної спільноти, а тому може свідчити про національнокультурний досвід і традиції...Фраземи, які відображають типові уявлення, можуть виконувати роль еталонів, стереотипів культурно-національного світобачення чи вказувати на їх символічний характер і в цій якості виступають як мовні експонати культурних знаків» [17, с. 213-238].

Аналогічну позицію поділяє у своїх дослідженнях лінгвіст Б. Ларін. На його думку, фразеологічний рівень мови найбільш детально показує 
специфіку мовної картини світу та виявляє взаємозв'язок культури й мови. Особливо рельєфно ця проблема визначається при лінгвокультурологічному аналізі фразем. Науковець зазначає, що «фразеологізми будь-якої мови передають риси національного характеру, способу життя, суспільний устрій народу, його культуру, світосприйняття, вони відображають ідеологію епохи, як світло ранку відбивається в краплі роси» [9].

Етнолінгвістику розглядають в основному як науку об'єктом дослідження якої $є$ мова в їі відношенні до культури. Але разом із тим комплексно аналізують народну психологію і міфологію. Тобто це наукова галузь, яка межує з власне лінгвістикою, фольклористикою, етнографією, культурологією i сьогодні розвивається. Етнолінгвістика також має фразему предметом дослідження. Відомо, що в основі світогляду кожного народу знаходиться система предметних значень, когнітивних схем, соціальних стереотипів. Саме через це свідомість індивідуума завжди обумовлена етнічно. Етнокультурні асоціації, емоційні реакції, етнічно марковані оцінки, еталони й стереотипи поведінки носія етнічної свідомості впливають на культурну конотацію фраземного знака. Етнолінгвістика орієнтована в основному на «історично-реконструктивний план виявлення культурних пластів у формуванні фразеології» [17, с. 217].

У різних лінгвістичних сферах фразема як термін розглядається зокрема у лінгвокультурологї (Б. Ларін, В. Телія), в етнолінгвістиці (В. Жайворонок, В. Васильченко, В. Кононенко, В. Коваль, В. Мокієнко, Е. Солодухо, Н. Ворокова), власне у фразеологї (М. Демський, М. Алефіренко, В. Ужченко, Л. Скрипник, М. Філіпчук, В. Баран, та ін.).

У лінгвістів різні позиції щодо історико-етимологічної основи терміна «фразема». М. Алефіренко, досліджуючи власне фразеологію, під фраземою розглядає «аналітичний за формою, але семантично цілісний i синтаксично неподільний мовний знак, який своїм виникненням i функціонуванням зобов'язаний комбінаторній взаємодії значень лексичних і граматичних компонентів свого вільносинтаксичного генотипу» [1, с. 12]. О. Селіванова кваліфікує фразему як інваріантну одиницю фраземного рівня: «Установлення співвідношення фразем з одиницями інших мовних рівнів може слугувати одним із доказів системності фразеології, ii проміжного статусу в рівневій ієрархії системи мови» [11, с.958]. М. Демський пропонує розглядати фразему як словосполучення, яке «за своєю номінативною функцією в багатьох мовах збігається зі словом, оскільки і лексема, i фразема виражають певне поняття i позначають предмети, ознаки, дії» [6, с. 7]. Лінгвіст доводить, що головна відмінність між лексемою і фраземою полягає саме в структурі цих одиниць. Якщо лексема - це цільнооформлена одиниця, значення якої детермінується значенням іï морфологічних компонентів, то фразема - нарізнооформлена одиниця, що складається 3 двох чи більше окремих лексем. Визначаючи сутність фраземи, їі ономасіологічні функції та системні особливості, М. 
Демський одним із перших надає фраземі статусу базової одиниці фраземного рівня, «що має фраземне значення, компонентний склад i граматичне значення - інтегранти відповідних граматичних категорій та виконує номінативно-конотативну функцію» [6, с. 5-6], а також звертає увагу на аспект генезису та способи творення українських фразем.

Близька до лексикологічного рівня фразема разом зі словом виступає цілісним живим механізмом на етапах еволюційного розвитку: виникнення (творення), становлення, активізації / пасивізації вжитку, зникнення.

Н. Стрілець займалася дослідженням фраземи і доводить, що «фразема - це непредикативна двовершинна фразеологічна одиниця, що складається як мінімум із двох самостійних слів і яка в семантичному плані може мати односторонню (фразеологічні єдності) або двосторонню (фразеологічні зрощення або ідіоми) смислову залежність» [17]. Науковець запропонувала авторську структурно-семантичну класифікацію фразем, в якій двовершинні непредикативні одиниці (фраземи) членуються семантично на ідіоми (одиниці 3 двосторонньою смисловою залежністю) та одиниці з односторонньою смисловою залежністю.

В. Архангельський подає класифікацію фразеологічних одиниць за семантичними ознаками та граматичною формою. Лінгвіст пропонує фразеологічні одиниці поділити на стійкі фрази та фраземи. Термін «стійка фраза» охоплює фразеологічні одиниці зі структурою речень, а термін «фразема»- фразеологічні одиниці зі структурою словосполучень.

Із часом термін «фразема» актуалізується у зв'язку зі зміною сучасних напрямів дослідження, зокрема вивчення безпосередньо фраземних одиниць із погляду внутрішньої форми, етимологічних процесів творення, функціонування в контексті мовленнєвого суспільного дискурсу та його міжвидових розгалужень - політичних, культурологічних, соціологічних тощо, на відміну від загальнонаукових, системних вивчень розділу (методологічні i теоретичні засади фразеологічного складу мови, системний і рівневий статус фразеологізмів, синтаксична роль тощо) [14].

Внутрішні форми фразем визначають особливості відображення в ідіоматиці етнокультурних пріоритетів, звичаїв, прихованих психологічних, моральних установок культурної спільноти. Вивчаючи внутрішні форми фразем будь-якої мови, підсвідомо потрапляєш у духовний світ народу і в міфологію. Фраземіка переходить із покоління в покоління не змінюючись, чого не можна сказати ні про який інший рівень мови. Дійсно, «фраземи - це «код культури»: часто в ньому зашифрований цілий сюжет» [16, с. 224]. Водночас фразема компактна, економна.

Часто до складу фразем входять слова, які відображають національну специфіку. Несе етнологічну інформацію також і внутрішня форма фразеологізмів. Стійкі словосполучення та інші фразеологічні одиниці, які віддзеркалюють етнічну специфіку світосприйняття тієї чи тієї

๑) І. В. Кевлюк, 2011. 
нації, мають у лінгвістиці різноманітні назви: «ідіоматика, яка законсервувала культурологічні релікти» (В. Мокієнко), «сакральна народна фразеологія» (Н. Толстой), «фразеологізми-міфологеми» (В. Маслова). Майже кожен термін підкреслює внутрішній зміст такого роду фразем. Аналізуючи взаємозв'язок культурно-етнографічних факторів i фразем, Є. Брисіна використовує термін «етнофраземіка» як розділ етнолінгвістики, «яка досліджує семантичні, експресивностилістичні властивості фраземних знаків, особливості їх творення i вживання в тісному зв'язку з етнічною історією і культурою народу - носія мови» [2]. Термін етнофразема, який вживає у своїх роботах Є. Брисіна, «у сукупному вигляді вказує на ідіоетнічну специфіку фразеологічної одиниці» [2]. До етнофразем вона відносить як немотивовану чи частково мотивовану на синхронному рівні обрядову й необрядову фразеологію, так i повністю мотивовані вирази, зв'язані 3 традиціями, звичаями, історичними фактами й культурою. Будь-яка фразема, вважає Н. Ворокова, має свій прототип, тобто вільне словосполучення, яке лежить в основі цієї фраземи. В прототипах описані відповідні ситуації, які віддзеркалюють різні сторони життя народу [5]. Поділяє дану точку зору і В. Васильченко: «Фразеологізми, несучи у собі залишки різних (родинних, календарних) давніх обрядів, разом з рештою стійких мовних одиниць, що відображають стихію народної духовної культури (етнофраземи), утворюють сакральну народну фразеологію» [4]. Отже, у фразеології, етнолінгвістиці та лінгвокультурології віддзеркалюється безпосередня мовна дійсність через призму національного складу мислення. А тому національно-культурну специфіку слід шукати саме у фраземах.

\section{Література}

1. Алефиренко Н. Ф. Проблемы фразеологического значения и смысла. - Астрахань : Изд-во Астраханского гос. педагогического ун-та, 2000. - 220 c.

2. Брысина Е. В. Этнолингвокультурологические основы диалектной фраземики Дона : дисс. докт... филол. наук. - Волгоград, 2003. -543 с.

3. Васильченко В. М. Этнофразеологизмы: точки пересечения этнокультуры и этноязыка // Основные вопросы лингвистики, лингводидактики и межкультурной коммуникации [Текст] : сб. научн. трудов по филологии / отв. ред. Г. В. Рябичкина. - Астрахань : Издательство : Сорокин Роман Васильевич, 2008. - № 2 (2). 0; С. 32-38.

4. Васильченко В. М. Обрядовомотиваційні зв'язки українських етнофразем (на матеріалі поховальних фразеологізмів) / В. М. Васильченко // Українська мова. - 2009. - № 2. - С. 70-85.

5. Ворокова Н. А. Этнокультурная специфика идиоматики (на материале русского и кабардиночеркесского языков) : дисс. докт. филол. наук. - Нальчик, 2003. -264 с.

6. Демський М. Українська фраземіка (дериваційна база, семантико-граматичні особливості) : автореф. дис. на здобуття наук. ступеня д-ра філол. наук / М. Демський. - Ужгород, 1994. - 21с.

7. Демський М. Українські фраземи і особливості їх творення / М. Демський. - Львів : Просвіта, 1994. $-62 \mathrm{c}$.

8. Загнітко А. Сучасний тлумачний словник української мови / А. Загнітко. - Донецьк : ТОВ ВКФ «Бао», 2009. - 960 c.

9. Ларин Б. А. Очерки по фразеологии // История русского языка и общее языкознание / Б. А. Ларин. - М. : Просвещение, 1977. - 224 с.

10. Laffal J. A Concept Dictionary of English (1973);

11. Селіванова О. Сучасна лінгвістика: термінологічна енциклопедія / О. Селіванова. - Полтава : Довкілля. - Київ, 2006. - 716 с.

12. Словник символів культури України / За ред. В. Коцура, О. Потапенка, М. Дмитренка (2002); 
13. Słownik stereotypów i symboli ludowych / Koncepcija całości i redakcja: Jerzy Bartmiński (1996, 1999);

14. Стахова В. Поняттєво-виражальна сутність «фраземіки» в українському лінгвотермінологічному просторі / В. Стахова // Мандрівець. Всеукраїнський науковий журнал : Серія філологічна. - Тернопіль, 2010. - №3. - С. 76-80.

15. Стрілець Н. Я. Структурні та функціонально-семантичні особливості соматичних фразем у романських мовах : дис. канд... філол. наук. - Львів, 2002. - 182 с.

16. Телия В. Н. Русская фразеология. Семантический, прагматический и лингвокультурологический аспекты / В. Н. Телия. - М. : Школа «Языки русской культуры», 1996. - 288 с.

17. Телия В. Н. Что такое фразеология? / В. Н. Телия. - М., 1966. - С. 213-238. 